雑草研究 Vol. 35 (4) 317 324（1990）

Weed Research, Japan

\title{
栽培技術の変遷に伴う雑草群落の変化
}

\author{
一牧草地一
}

根本正之 農林水産省農業環境技術研究所

\begin{abstract}
Masayuki Nemoto: Changes of the Weed Flora Caused by Changes of Cultivation Techniques — Sown Grasslands-
\end{abstract}

わが国の牧草地面積は戦後の粗飼料生産を基盤と する畜産の振興と相俟って急速に拡大した。1949年 の飼料作物・牧草栽培面積はわずか 6.6 万haに過ぎ なかったが，その後毎年増加し，1984年には 102.7 万ha となった。そのうち牧草地面積は71.4万haで全 体の約 $70 \%$ に相当する ${ }^{59)}$ 。わが国の粗飼料は主とし て牧草地と飼料作物畑で生産されるが, その比率に は北日本と南日本で著しく異なるという特徵がある。 すなわち北海道や東北では牧草地と飼料作物畑の比 率が 9：1で, 冷涼な気候条件に適した省力向きの 牧草が主体であるのに対し, 関東より九州に至る温 暖地〜西南暖地では温暖気候を利用する集約多毛作 型の飼料作物に重点が置かれている。そのため両者 の比率は $2: 8$ で牧草地の面積比が極端に小さくな つている59)。

毎年着実に拡大してきた草地面積は1984年を境に その増加が止まり ${ }^{43)}$, その後は牧草の面積当りの量 と質の向上と, 草地利用の高度化に重点が置かれて きた。これは草地畜産の目標が草地造成から草地の 維持管理に移行したことを示すものであろう。具体 的には地域の環境条件に適した，多収性で良質な牧 草の種や品種の選定と育種を行う一方で, 土地規模, 家畜の種類, 頭数, 労働手段などの経営条件を加味 した総合的知見に立っての省力, 安定, 多収性, 調 整加工適性あるいは家畜利用適性を高める方向で近 年の栽培・管理技術が進展していると言えよう ${ }^{59) 。 ~}$

ところでわが国の牧草地雑草に関する研究は1978

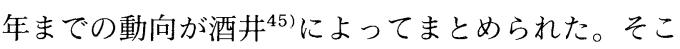
で本稿ではその後に行われた草地畜産における研究 の進展状況をふまえて, 栽培管理技術および雑草群 落をめぐる諸問題について検討してみたい。

\section{1. 牧草地雑草の特性}

\section{(1) 雑草の定義}

これまで雑草はもっぱら栽培植物との関係で定義 してきたが，最近では当該植物が侵入・生育してい
る場の環境条件によって定義する仕方も広まってい る ${ }^{13)}$ 。具体的には “何らかの人為的攪乱が加えられ る場に生育している一群の植物”が雑草と言うこと になる。しかし本稿で取り扱う雑草は牧草地という 場に限られるわけだから，牧草または喫食家畜との 関係からそれを定義するのが妥当であろう。

牧草地雑草の定義には(1)家音の生産目的に添わな い植物または有害か有毒な植物, (2)一般に牧草と定 義されている以外の植物, (3)播種した牧草以外の植 物などがあり ${ }^{45)}$, 研究者によってその取り扱う範囲 が異なっている。

水田作や畑作では雑草の侵入・発生が直接的に目 的とする作物の収量に結びつく場合が多いので，雑 草の定義は左程やっかいでないだろう。ところが牧 草地で栽培される牧草は家畜生産にどれだけ寄与で きたかによって価值が決ってくるので雑草を牧草と の相互作用のみに焦点を絞り込んで取り扱うわけに はいかない。従って牧草栽培・管理の立場からは(1) の定義が現実的であるが, 牧草地雑草一般について 論ずる場合は，はなはだ不便である。

例えばわが国の牧草地の問題雑草中第 3 位にある ヨモギ類は (第 1 表), 中国, 内蒙古のステップ地 帯では重要な飼料植物でもあるからだ。有害植物あ るいは有毒植物を除けば, 当該植物が草食家畜の生 産目的に添う添わないは経営条件の如何で決ってく るものであり，それによって問題雑草であったりな かったりするからである。

次に(2)の定義では(1)とは逆の意味で不都合を生ず る場合があろう。例えば牧草と定義されているレッ ドトップが, 牧草としての㕰好性や生産性に勝るオ 一チャードグラスやチモシーの優占する草地に侵入 した場合は“コヌカグサ”という雑草となる “。

筆者は従来から牧草地雑草として取り扱う植物の 範囲を(3の定義に従って論じて来た。本稿でもまず 播種した牧草以外の植物を雑草と定義した上で, 牧 草生産と家畜生産の両面から，その特性について概 
第 1 表 公共育成牧場における問題雑草指摘牧場数

\begin{tabular}{|c|c|c|c|c|c|c|c|}
\hline & 草名 & 全国 & 北海道 & 東北 & 関東～四国 & 九州 & 沖縄 \\
\hline 1 & 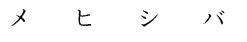 & 115 & 7 & 37 & 47(4) & 24(2) & \\
\hline 2 & エノコログサ & 25 & 3 & 1 & 13 & 8 & \\
\hline 3 & スズメノカタビラ & 21 & 6 & 11 & 4 & 0 & \\
\hline 4 & 八 $\quad$ カ & 73 & 8 & 26 & 26 & 13 & \\
\hline 5 & エゾノギシギシ & 549 (1) & 1331) & 233(1) & $130(2)$ & $53(1)$ & \\
\hline 6 & ヒメス イ バ & 59 & 3 & 26 & 27 & 3 & \\
\hline 7 & イタド & 155 & $51(5)$ & $63(5)$ & 39 & 2 & \\
\hline 8 & イ ヌ 夕 デ & 57 & 16 & 9 & 16 & 16(4) & \\
\hline 9 & フ & $207(4)$ & $114(2)$ & $67(4)$ & 28 & 0 & \\
\hline 10 & オニアザミ & 203(5) & $104(3)$ & 40 & $47(4)$ & 12 & \\
\hline 11 & タン ポ ポ & 198 & 48 & 31 & 18 & 1 & \\
\hline 12 & $\exists \quad$ モ & $310(3)$ & $97(4)$ & 131(3) & $65(3)$ & $16(4)$ & 1 \\
\hline 13 & ヒメジョオン & 24 & 8 & 2 & 10 & 4 & \\
\hline 14 & ヒメムカショモギ & 29 & 3 & 15 & 10 & 1 & \\
\hline 15 & アレチノギク & 36 & 2 & 2 & 19 & 12 & 1 \\
\hline 16 & ノコギリソウ & 12 & 3 & 2 & 6 & 1 & \\
\hline 17 & イ ヌ ビ エ & 36 & 3 & 14 & 14 & 5 & \\
\hline 18 & 八 $コ$ べ & 47 & 17 & 16 & 7 & 7 & \\
\hline 19 & ミ ミ ナ グ サ & 3 & 2 & 1 & 0 & 0 & \\
\hline 20 & チ ド メ & 8 & 0 & 2 & 1 & 5 & \\
\hline 21 & ヘラオオバコ & 39 & 14 & 14 & 9 & 2 & \\
\hline 22 & ワルナス ビ & 5 & 1 & 1 & 2 & 1 & \\
\hline 23 & ワラ & $376(2)$ & 23 & 195(2) & 139(1). & $18(3)$ & 1 \\
\hline 24 & 他 & 240 & 53 & 72 & 97 & 8 & 10 \\
\hline & 該 当 牧 場 数 & 1,236 & 354 & 460 & 317 & 94 & 11 \\
\hline
\end{tabular}

注）複数回答, ○内数字は上位種順位。 （草地協会悉皆調査1981）, 粗飼料・草地ハンドブック（1989）による。

述したい。

牧草生産の観点に立てば, 採草地雑草は大型雑草 と小型雑草に分けることができる ${ }^{36)}$ 。大型雑草とは なんらかの条件の変化に伴って採草地に侵入, 発生 し, 牧草と競争関係を生ずる可能性の大きな雑草で ある。他方, 小型雑草とは, 通常の刈取り条件下で 牧草と空間的，時間的にすみ分けて生活が可能な種 である。前者にはエゾノギシギシ, イタドリ，ヨモ ギ，七メジョオン等が，後者にはオランダミミナグ サ，八コベ，ツメクサ等が属している。また雑草の 生育型に着目すれば陣地拡大型 (PE 型) 雑草と陣地 強化型 (PF 型) 雑草に分けることもできよう ${ }^{41)}$ 。

一方, 家畜生産の観点に立つのなら, 牧草地雑草 を有毒植物 (Poisonous plants), 有害植物 (Harmful plants), 不嗜好性植物 (Unpalatable plants), 低生産 性植物 (Unproductive plants) の 4 つのカテゴリー に分類するのがよいであろう2゙。わが国で知られて いる主要な有毒植物を第 2 表に示した ${ }^{11)}$ 。有毒植物 は採食した家畜に中毒を起こさせるわけだから必ず 除去しなければならない。有害植物とは物理的に家
畜を傷つけるもので，ナワシロイチゴ，ノイバラ， タラノキ等の有棘灌木が含まれる。不嗜好性植物と は普通は家畜が採食しない植物で, それが生育して いると嗜好性の高い植物の生長を抑制する種である。 例えばイラクサやセイヨウトゲアザミ ${ }^{2)}$ があり，北 海道で問題となっているシバムギ ${ }^{5,7)}$ や九州でのチ カラシバもこのカテゴリーに入るであろう。シバム ギやチカラシバのような多年生イネ科雑草はどの程 度発生した時に防除すべきなのか, 当該草地に課せ られた生産性や利用効率を考慮した上で決めるべき であろう。スズメノカタビラのように嗜好性はあっ ても生産力の低い植物が低生産性植物である。牧草 の量と質が乳量や乳質に大きく影響してくる酪農経 営で, その集約度が高い牧草地では低生産性植物が 発生すること自体が好ましくないであろう。しかし 肉牛の育成やめん羊の放牧地では多少, 牧草の密度 が低下しても，スズメノカタビラによって地表面が 覆われている方が好ましい。スズメノカタビラは小 型雑草でもあり，その裸地をカバーする性質を活用 すれば有害植物や不嗜好性植物の侵入を防止するこ 
第 2 表 牧草地における主要な有毒植物

\begin{tabular}{|c|c|c|c|c|c|c|c|}
\hline & 雑 & 草 & & 名 & 区 分 & 有 晴 部 位 & 毒 成 \\
\hline \multicolumn{4}{|c|}{ チョウセンアサガオ } & ナ & 一 年 草 & 全草, とくに種子 & アルカロイド \\
\hline イ & ヌ & ホウ ズ & キ & ナ & 一年草 & 川 漿果 & (ソラニン) \\
\hline & y & ノボ夕 & ン & キンポウゲ & 多年 草 & 全草 & プロトアネモニン \\
\hline イ & 又 & ス ギ & ナ & トク サ & 多年草 & $\prime \prime$ & アルカロイド \\
\hline 夕 & ケ & $=ク ゙$ & サ & ケ & 多年草 & $\prime \prime$ & アルカロイド \\
\hline 七 & נוd & ンバ & ナ & ヒガンバナ & 多年草 & " , とくに根部 & アルカロイド \\
\hline ワ & & ラ & ビ & ウラボ シ & 多年 草 & 全草 & プタキロイド \\
\hline r & , & カ ブ & 卜 & キンポウゲ & 多年 草 & " , とくに根, 種子 & アルカロイド \\
\hline ア & & 七 & ビ & ツ ツ ジ & 常緑灌木 & ", $"$ 新葉 & グラヤノトキシン \\
\hline ネ & & ジ & キ & ツ ツ ジ & 落葉灌木 & $"$, $"$ 新葉 & リオニオール A \\
\hline
\end{tabular}

注）このほか，レンゲッッジ，二セアカシア，ドクゼリ，ヒメスイバ，エゾネギ，七マな ど多数。植調21（1987）による。

\section{ともできるであろう。}

牧草地雑草を栽培・管理技術の側面から定義する 上で最も問題となるのは草地の集約度の違いによっ て発生雑草の位置づけが微妙に変化することである。

\section{(2) 雑草発生の様相}

草地に侵入・発生する雑草の様相は, 草地造成の 初期と牧草の利用期間では著しく異なる。牧草を播 種してそれが定着するまでの期間が侵入雑草には最 も好都合である。

雑草の発生しやすさは牧草の播種密度, 初期生長 速度, 施肥量等によって左右される ${ }^{2)} 。$ 。播種密度が 高い程, 雑草は発生しにくく, またライグラスのよ うに初期生長の早い牧草ほど雑草が繁茂しにくい。 逆に地上部の生育繁茂が左程でないアルファルファ 草地では雑草害が出やすい ${ }^{12,55)}$ 。アルファルファの 初期生長を早め, 草地内の裸地を早急に縮少するた めにはある程度の施肥が必要である。さらに牧草の 播種時期による影響も極めて大きく, 春季に播種し た場合, イヌタデ, イヌビエ, メヒシバ, イヌビュ 等の大発生の結果，草地造成に失敗する場合も多い。

一般に造成直後は一年生雑草の発生が顕著である が51)，不耕起造成草地で前植生の抑圧が不完全な場 合は, ノイバラ, ナワシロイチゴ, タラノキ等の雑 灌木の再生や侵入が問題となる ${ }^{59)}$ (第 3 表)。その後 牧草の定着に成功すれば雑草は一時期減少する。し かし年次の経過とともに多年生雑草が増加し, 牧草 密度の減少や裸地が出現しやすくなり牧草地は老化 する。

全国的にみて出現頻度の高い雑草はエゾノギシギ シ, オオバコ, ヒメジョオン, ヒメムカショモギ,
ハコベ，ヒメスイバなどである ${ }^{51)}$ 。一方，問題雑草 は第 1 表に示したとおり, エゾノギシギシ, ワラビ, ヨモギ，フキ，オニアザミ，タンポポ，イタドリ, メヒシバの順で ${ }^{26)}$ ，エゾノギシギシが際立っている。 しかしながら必ずしも出現頻度の高い雑草と問題雑 草はパラレルな関係にないことがわかる。

また北海道や東北では多年生雑草が問題になって いるのに対し，温暖地〜西南暖地ではメヒシバ，イ ヌタデ等の一年生雑草が問題とされる割合が高い

(第 1 表)。この事実は温暖地〜西南暖地では草地 造成初期から雑草害が問題になることを物語ってい ると言えるであろう。

\section{(3) 牧草地雑草の生態}

上記のように牧草地での出現頻度が高く，かつ問 題意識も極めて高いエゾノギシギシはわが国牧草地 雑草の代表といってよく, 牧草地雑草の種生態的研 究の 8 割近くがエゾノギシギシの生態と防除に関す るものである。そこで以下エゾノギシギシを中心に 主要雑草の種生態的研究の動向を牧草栽培管理との 係わりから述べたい。

エゾノギシギシは明治年間に牧草の導入に伴って 欧米から侵入した帰化植物である。当初は北海道の 牧草地で多発したが, 最近は九州方面でも問題雑草 のトップの座を占めるに至った（第 1 表）。

わが国には約15種のギシギシ属植物の分布が知ら れているが44), 何故エゾノギシギシが際立って牧草 地の雑草になっているのであろうか。他のギシギシ 属植物と比較検討することによってその強害草とし ての $2 \sim 3$ の生理・生態的特性が明らかになった。 ギシギシ属のなかで普通にみられるギシギシ, ス 
第 3 表 牧草地における主な雑灌木

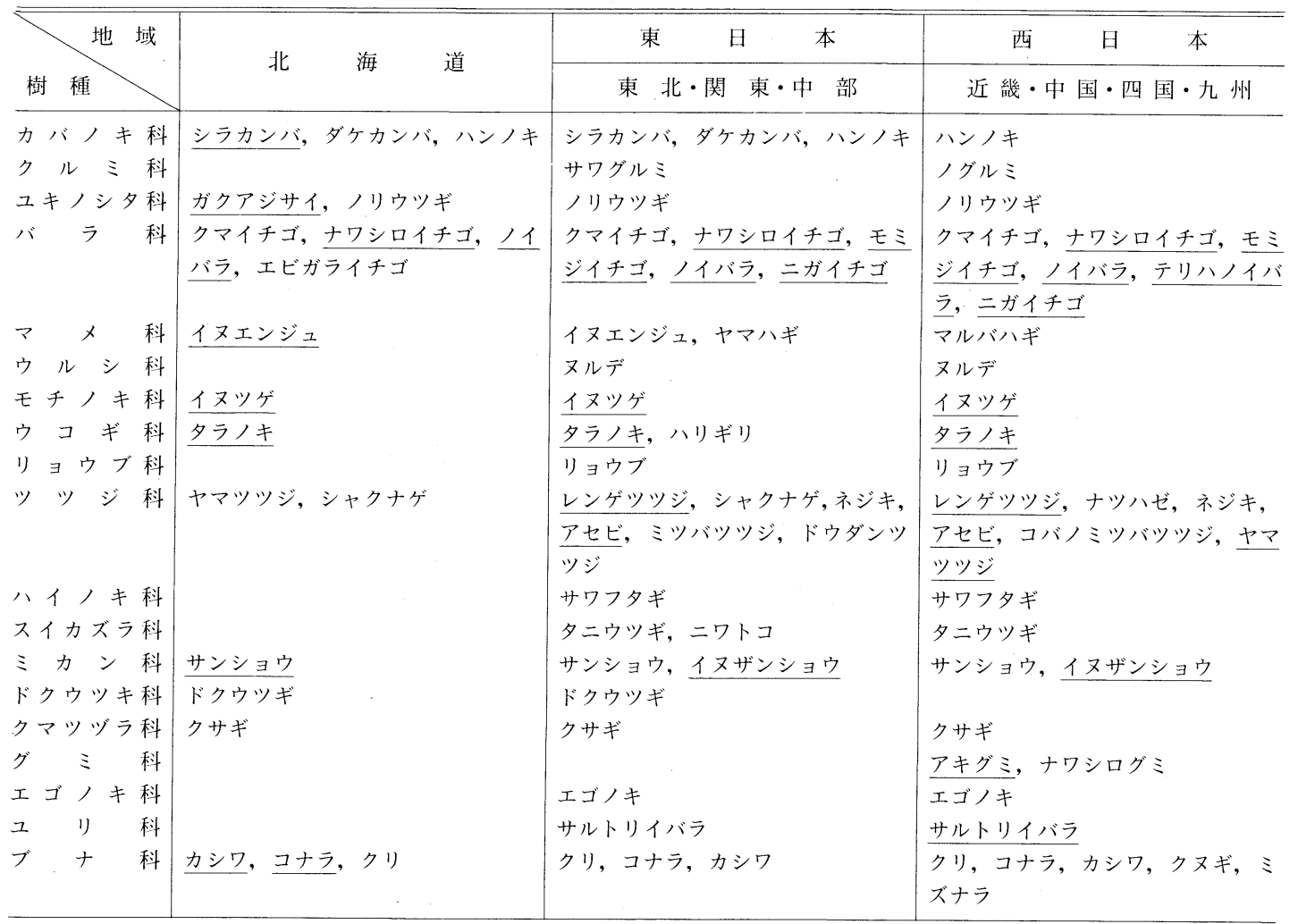

注）——はれぞれの地域において，特に不良雑灌木となっているものを示す。

(草地協会1981)，粗飼料・草地ハンドブック（1989）による。

イバ，ナガバギシギシ，アレチギシギシ，ヒメスイ バを供試してエゾノギシギシと同一の富栄養条件下 で栽培した。その結果エゾノギシギシはギシギシや ナガバギシギシの開花・結実パターンとほぼ同様で あったが, 種子生産量は他のいずれの種よりも著し く多く，個体間相互作用のない孤立個体で 10 万個以 上の種子を生産した ${ }^{40)}$ 。このようにエゾノギシギシ は富栄養条件，特に窒素とリンによく反応し ${ }^{14,21)}$, しかも低リン耐性および高アルミニウム耐性に勝 る ${ }^{10)}$ 。そこでリン欠乏や高アルミニウムの害が問題 となりやすい火山灰土壤に造成した牧草地の多いわ が国ではエゾノギシギシがナガバギシギシ，アレチ ギシギシ，ギシギシよりもよく適応し，広く分布す るのであろう。また北海道東部において, エゾノギ シギシとナガバギシギシの生長と種子生産に及ぼす 刈取りの影響を調査した結果 ${ }^{8,9)}$, 種子の登熟期以 降に刈取ると, 再生後の種子生産量は明らかにエゾ ノギシギシが勝ることが判明した。

エゾノギシギシの発芽はその発生を抑止する上か

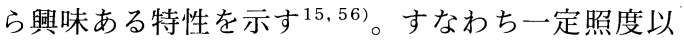
上の明条件下あるいは暗黒下では旺盛に発芽するが, 牧草に充分に被われている弱光下では発芽が抑制さ れる。草地内の裸地ではその部分が拡大してくると 牧草の影響が少なくなり光量だけでなく赤色光の割 合が高まるため発芽可能となるようである。エゾノ ギシギシや他の雑草について, さらに群落内の光質 の変化と発芽との関係について明らかにする必要が あろう。

牧草地におけるエゾノギシギシ個体の消長を明ら かにすることはその防除法を確立する上から重要で あり, 北海道, 東北, 関東の各地でその実体が調べ

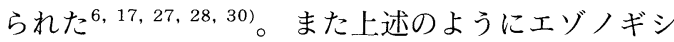
ギシの発芽, 生長に対して牧草地内の裸地がはたす 役割は大きく, 裸地の形状とエゾノギシギシの生 育 $^{38)}$, 種子サイズと裸地面積 ${ }^{31)}$ の関係などが明らか にされつつある。一方，ポット栽培試験に基づくエ ゾノギシギシ孤立個体の生活史 ${ }^{16)} も$ 明らかにされた が, 牧草地群落内ではそれが牧草から干渉作用を受 
ける結果，どのように変化するのかあるいはしない のかさらに研究の深化が望まれる。

エゾノギシギシの防除は除草剤 ${ }^{11,54)}$ と生態的手 法による ${ }^{34,37)} も の の$ 両面から研究がなされている が, 生態的防除を中心とした総合的防除法によるの が望ましいであろう ${ }^{21)}$ 。例えば西南暖地のエゾノギ シギシが大発生した牧草地でアシュラムとグリホサ 一トを使用してエゾノギシギシを抑圧し, 草地更新 を試みたが, 経費 ${ }^{1)}$, 効果, 未知の薬害などを考慮 すると除草剤のみによる防除はまだ問題がある ${ }^{41}$ 。

エゾノギシギシ以外の草地雑草の生態について はワラビ23, 24), ヨモギ32), オニアザミ ${ }^{19)}$, メヒシ バ29)，ワルナスビ25)，シバムギ5,7) 等について僅か ばかりの研究がなされているに過ぎず今後の研究が 期待される。

\section{2. 雑草からみた最近の牧草栽培管理上の 2,3 の特色}

\section{(1) 牧草地の効率的な維持法と雑草群落}

上述のように温暖地〜西南暖地における雑草発生 の様相は北海道や東北地方とはかなり異なり, 造成 の初期から雑草害が著しく, 牧草地管理上で最も やっかいなのが雑草対策であるとまで言われてい る ${ }^{42)}$ 。阿蘇久住高原の牧草地ではエゾノギシギシ, チカラシバ, イヌビユ, ヒメクグ, チドメグサ, シ ラゲガヤ，イタドリ等40種以上の雑草が発生する。 そこで西村 ${ }^{42}$ は雑草発生を防止する観点から, 草地 内の裸地発生を極力抑える方式，すなわち “牧草の 密生過繁茂 $\rightarrow$ 高刈り $\rightarrow$ ダイレクトカットーサイレー ジ”と言う草地利用技術体系を確立した。ダイレク トカット方式では牧草地内での作業機械類の踏圧が 最少限で済み牧草のいたみが少ない。また夏場の施 肥はイヌビユ，ヒメクグ，イヌタデ，メヒシバ，エ ノコログサなどの夏雑草の繁茂を促進させる場合が 多いので追肥は行わない ${ }^{42)}$

西南暖地では放牧利用のための牧草として, 蹄圧 に強く, かつ越冬性に優れたバヒアグラスが適草種 の一つと考えられている。ところでバヒアグラス草 地造成の問題点の一つは, バヒアグラスの初期生長 が遅いため, 雑草に被圧されその優占草地になるま でに長期間を要することである。そこでバヒアグラ 又草地造成時に前駆植物として寒地型牧草であるぺ レニアルライグラス, トールフェスク, ケンタッキ ーブルーグラス, レッドトップ，ホワイトクローバ 一を混播した。その結果, 寒地型牧草の生長が比較 的不良で, 他方バヒアグラスが年次の経過に伴って
優占する南向斜面では越年生雑草であるカモジグサ やオオアレチノギクの侵入, 発生を抑圧することが できた ${ }^{57,58) 。 ~}$

アルファルファ栽培ではハコベ，ナズナ，ギシギ シ等の広葉雑草がよく繁茂するが55), 温暖地でアル ファルファを栽培する場合は初期生育時における雑 草対策が重要な鍵であり，早播き，年内刈りの栽培 体系が安定した栽培法の一つになるのではないかと 考えられている ${ }^{12)}$ 。

また栃木県那須の草地試では寒地型牧草の代表種 であるオーチャードグラスとエゾノギシギシあるい はメヒシバの空間分布に着目した一連の草地管理に 関する研究が行われた ${ }^{27,28,30,31) 。 ~}$

\section{(2) 除草剤による牧草地植生の制御}

わが国の牧草地面積は上述のように 70 万ha以上あ るが，牧草用の除草剤として登録されているのは, わずかにアシュラム液剤, グリホサート液凨, DBN 粒剂, MCPB 液剤の 4 種類のみである ${ }^{11)}$ 。

最近はワラビ ${ }^{23)}$, ワルナスビ ${ }^{25)}$, シバムギ7)等, 草種別の除草剤試験と並行して，除草剤を使用した 草地更新前植生のコントロールに関心がはらわれる ようになった ${ }^{221}$ 。近年, 牧草地の低コスト更新法の 必要性が認識されるに及び, その一手段として除草 凬を使用することが考えられはじめた。

例えばシバムギ，エゾノギシギシ，ワラビなど多 年生雑草の多い草地では耕起 2 週間前にグリホサー 卜剂を処理，前植生を枯殺してから牧草を播種する。 また前植生が枯死した後で地表面近くのエゾノギシ ギシ種子が大量に発芽した場合はアシュラムで枯殺 する方法がある ${ }^{22)}$ 。西南暖地でエゾノギシギシが大 発生した草地の更新にも同様の方法が試みられてい る54)。またケンタッキーブルーグラスやレッドトッ プ等の生産性の低い前植生をグリホサート剂により 枯殺, 不耕起で簡易更新する試みもある ${ }^{3,4)}$ 。しか しいずれも技術としては未完成な点も多い22)。

さらに牧草地の植生全体をコントロールする立場 から除草剂の使用が試みられている ${ }^{22)}$ 。北海道で造 成後 $3 \sim 4$ 年目のアカクローバーが消失してしまっ た草地で，チモシーやオーチャードグラス等を除草 剤によって抑圧し, アカクローバーの幼植物を定着 させると言うものである。しかしながらイネ科牧草 の生長を止め, かつ殺さないと言う技術は微妙なコ ントロールが必要であり非常にむずかしい。もし前 植生を生かしつつ追播することに成功すれば牧草生 産を途中で中断しなくてもよいから経済的であろう。 草地更新や草地植生の組成改善に除草剂を利用する 
ための研究は比較的最近であり, 今後の研究蓄積が 望まれるところである。

\section{(3) 施肥と草地雑草}

近年, 家畜飼養頭数が急増したことから多量の堆 きゅう肥を牧草地に散布 ${ }^{39)}$ あるいはトウモロコシ 粕 $^{35)}$, ビール粕, 骨粉など産業廃棄物を有機質肥料 として牧草地へ還元することが盛んである。これら は牧草の生育を促進するだけに留まらず，八コべ, イヌタデ, ネズミムギ等の好窒素性植物の大発生を 引き起すことが多い。北海道で問題雑草となって いるコヌカグサ，シバムギ ${ }^{5,7)}$ ，アメリカオニアザ ミ ${ }^{19)} も$ 多量の窒素施用が増大の一要因となってい るようである。

一方, 無施肥, 不耕起でペレニアルライグラスと ケンタッキーブルーグラスを播種した場合には，越 冬前の生存個体は多くても, その後の生長が著しく 緩慢であり，ハルジオン，アキメヒシバ，シバ等の 雑草が発生し繁茂する ${ }^{18)}$ 。

逆に温暖地〜西南暖地で問題となるメヒシバは夏 季の施肥を少なくすることでその旺盛な生育を抑え ることができる ${ }^{29)}$ 。従って上述のように九州ではイ ヌビユ, ヒメクグ, イヌタデ, メヒシバ, エノコロ グサ等の夏雑草の発生が懸念される牧草地での追肥 は行わないのがよい42)ことになる。

肥料の種類や量に対する反応が牧草と雑草で異な るならば，施肥管理を通して雑草防除が可能になる 場合もあるだろう。このような立場から村山视 は 窒素, リン, カリが雑草の生育・重量および植生に 及ぼす影響について一連の研究を行ったが, アルフ アルファ栽培では窒素を抑制し, リンを重点的に施 用することで雑草を抑えることができるという。

\section{3. 今後の課題}

\section{（1）草地雑草防除の経済性について}

牧草地の雑草防除を進めるにあたってはその経済 的な裏付けを明確にすることが特に重要である。チ ヨウセンアサガオ, イヌホウズキ, アセビ, レンゲ ツツジ等の有毒植物の除去は言うまでもないが, 例 えば牧草地の最強害草と言われるエゾノギシギシを 如何なる手段で, どの時点で, どの程度除去するか は当該草地に生育する牧草にどれだけの価値がある かで決まってくる。そして牧草栽培では同一品種の 同一生育ステージの牧草であっても, 個々の草地経 営に抢けるその価值は著しく異なるからである。従 って今後は当該草地の自然環境, 社会的 - 人為的環 境 ${ }^{42)}$ に大きく依存している牧草の価値を常に念頭
に置いた雑草防除の手段, 時期, 回数, 範囲などを 決定するための手法の開発が望まれる。さらに除草 剤を使用する場合はその効果や薬害についても十分 検討すべきことは(54) 言うまでもない。

雑草が侵入してくるような環境が改まらない限り, 雑草防除は一時的なものであり, 再び雑草の侵入が 起るであろう。従って長期間にわたる雑草防除を達 成するためには, 雑草の侵入, 発生, 繁茂しやすい 環境条件や管理上の欠陥を正すことが基本となる ${ }^{2)}$ 。 また稲作や畑作と比較して収益性の低い牧草栽培て は，その栽培・管理法の改善に主眼を置いた生態的 方法を主体とする雑草防除体系を確立しなければな らないであろう ${ }^{36)}$

\section{（2）雑草による牧草地の状態診断手法の確立}

生態的に雑草を防除するためには，個々の雑草の 生理的あるいは種生態的特性を明らかにすると同時 に, 草地生態系内に侵入してきた様々な雑草が, そ れぞれどのような振舞をしているのかを, 雑草とそ れを取りまく環境との関係を通して明らかにするこ とが重要である。このような研究の基礎資料として 欠かせないのが牧草地における雑草群落動態調査で あり，北海道から沖縄に至るまで日本全国にわたつ て，その地域性に着目した調査が酒井らによってな

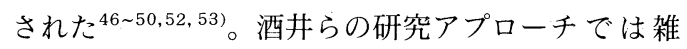
草群落動態を知ることと牧草地における牧草生産 力の動向を知ることは表裏一体であり, 概括的では あるが雑草群落を指標にした牧草生産力の動向や草 地状態診断, さらには予測 ${ }^{33,51)}$ が可能となった。

一方, 牧草地雑草管理の立場から, 牧草地におけ る雑草や牧草の空間分布パターン ${ }^{28)}$, 雑草侵入条件 下での牧草個体の減少 ${ }^{30)}$, エゾノギシギシの発芽, 初期生長におよぼす裸地面積 ${ }^{31)}$ あるいは裸地の形 状とエゾノギシギシの生育との関係 ${ }^{38)}$ など牧草地 内における雑草とその発生の場に関する研究がなさ れつつある。例えばエゾノギシギシのような強害雑 草でも, その発生・侵入初期段階では, 牧草地造成 の初期を除けば牧草よりも競争力が弱いのが一般的 のようだ。そこで周辺牧草から干渉を受けない空間 （裸地）が, 当該雑草の侵入から種子生産までの過 程でどの程度, 牧草地内に存在しているかが, 当該 雑草の発生予測上の目やすとなる。これまでほとん ど手の付けられていなかった, 牧草地内における雑 草の動態とそれを規制している侵入・定着の場に関 する研究が極めて重要である。

また草地雑草の中には小型雑草のようにマルチン グ効果によって結果的には牧草生産にとってプラス 
になる雑草もあり ${ }^{33)}$ ，この種の研究もさらに深化さ れることを期待したい。

どのような “場”に, どのような雑草が侵入・発 生しやすいか, また発生しても問題ないのかを, 圃 場実験と数学モデルを用いて定量的に把握できるよ うになれば，さらに正確な牧草地の状態診断と予測 が可能になるだろう。このようなきめの細かい診断 ・予測手法は今後, その開発が望まれている農家経 営の構成要素としての各牧草地ごとの適切な管理を 行う上で早急に開発されねばならない。

謝辞：本稿をまとめるにあたり, 農林水産省農業 研究センター畑雑草研究室長野口勝可博士からは査 読ならびに貴重な御意見をいただいた。記して謝意 を表します。

\section{引用 文 献}

1) DOYLE, C.J., A.K. OSWALD, R.J. HAGGAR and F. W. KIRKHAM (1984) : Weed Res. 24, 183 193.

2) HAGGAR, R.J., D. SOPER and W.F. CORMACK : In "Weed control handbook principles" ed. by R.J. HANCE and K. HOLLY. Eighth edition, Blackwell, Oxford, pp. 387 405 (1990).

3）早川嘉彦・近藤 熙(1987)：日草誌 33(3)，264～ 270 .

4）早川嘉彦・近藤 熙(1987)：日草誌 33(3)，271～ 275 .

5）本江昭夫・福永和男 (1982)：雑草研究 27 (1)，28 $\sim 33$.

6) HongO, A (1986) : Weed Res. Japan 31(4), 300 $\sim 305$.

7) 本江昭夫 (1988)：植調 22(4)，25 30.

8) Hongo, A (1988): Weed Res. Japan 33(1), 1 7.

9) HongO, A (1988) : Weed Res. Japan 33(1), 8〜 13.

10）堀江秀樹 - 根本正之（1988）：雑草研究 33(別), 195 196.

11）飯田克実(1987)：植調 $21(10) ， 2 \sim 9$.

12) 加藤 満 - 稲波 進 - 神戸三智雄 (1989) : 自給飼料 $11,20 \sim 24$.

13）河野昭一(1984）: 雑草研究 29(1)，1１0.

14）小林 聖 - 村山三郎 - 小阪進一 (1987) : 雑草研究 $32(1), 30 \sim 37$.

15）小林 聖-島影 孝・広田秀憲(1989) : 雑草研究 34 (4), 292 298.

16）小林 聖・藤浪寿夫・広田秀憲（1989）：日草誌 35 (3), 206 211.

17) MAKUChI, T. and H. SAKAI (1984): Weed Res.
Japan. 29(2), 123 130.

18）三田村強・須山哲男 - 村里正八 (1988) : 日草誌 $34(2), 92 \sim 99$.

19）村山三郎・小阪進一・山口佳寿子(1984)：北海道草 地研報 $18,1 \sim 6$.

20）村山三郎(1984)：京都大学学位審査論文.

21）村山三郎(1988)：植調 22(6), 9 16.

22) 名田陽一(1987)：植調 $21(8), 2 \sim 5$.

23）梨木 守・野本達郎 - 原島徳一(1980): : 雑草研究 25 (3), 214 216.

24）梨木 守・野本達郎・目黑良平(1984）：雑草研究 $29(1), 61 \sim 70$.

25）梨木 守. 野本達郎・目黑良平(1985）：雑草研究 30 (2), 131 136.

26）梨木 守・野本達郎・目黒良平・佐藤健次 (1986)： 雑草研究 31 (3), 221 227.

27）梨木 守・野本達郎・目黒良平 (1987)：雑草研究 $32(1), 25 \sim 29$.

28) 梨木 守・原島徳一・佐藤健次 (1987)：雑草研究 32 (4), $247 \sim 254$.

29）梨木 守・野本達郎・目黑良平(1988)：雑草研究 $33(1), 31 \sim 40$.

30）梨木 守・沢田 均・原島德一・佐藤健次 (1988)： 雑草研究 33(4), 253 259.

31）梨木 守・原島徳一・佐藤健次 (1989)：雑草研究 34 (4), 308 314.

32）根本正之(1979）：雑草研究 24(1)，12１8.

33) Nemoto, M : In "Biology and ecology of weeds" ed by W. HolzNeR and M. Numata. Junk, The Hague, pp. 395 401 (1982).

34）根本正之・小林茂樹・ 川島 笑・金木良三(1983)： 雑草研究 28(3), 198 204.

35) Nemoto, M. and S. Kobayashi (1984): J. of Agr. Science, Tokyo Univ. of Agr. 28(4), 375 382.

36）根本正之(1986)：雑草研究 $31(2) ， 102 \sim 107$.

37）根本正之(1986)：雑草研究 31(3)，244 251.

38）根本正之-是永博基（1987）: 雑草研究 32 (別), 103 104.

39）根本正之・赤池忠光・山中良忠(1990)：雑草研究 $35(1), 84 \sim 87$.

40) Nemoto, M (1990) : Proceedings 12nd APWSS (in press).

41）根本正之・山形与志樹(1990）: 草地生態 (27), 1 $\sim 14$.

42）西村光博(1984)：自給飼料 $2,37 \sim 42$.

43）農林水産省統計情報部：第63次農林水産省統計表, 農林統計協会, 東京, p. 114 (1988).

44）奥田重俊：「現代生態学の断面」, 共立出版, 東京, pp. 85 95 (1983). 
45) 酒井 博(1978)：雑草研究 23(3)，151 159.

46）酒井 博 - 佐藤徳雄 - 奥田重俊 - 川鍋祐夫 (1979)： 雑草研究 $24(3), 176 \sim 181$.

47) 酒井 博 - 佐藤徳雄 - 奥田重俊 - 川鍋祐夫 (1979)： 雑草研究 $24(3) ， 182 \sim 187$.

48) 酒井 博 - 佐藤徳雄 - 奥田重俊 - 秋山 㑆(1980)： 雑草研究 $25(1), 17 \sim 23$.

49) 酒井 博 - 佐藤徳雄 - 奥田重俊 - 秋山 㑆(1980)： 雑草研究 $25(1), 24 \sim 29$.

50) 酒井 博 - 佐藤徳雄 - 奥田重俊 - 秋山 㑆(1982)： 雑草研究 $27(4), 251 \sim 258$.

51) 酒井 博 (1984)：雑草研究 $29(3) ， 190 \sim 202$.

52) 酒井 博 - 佐藤徳雄 - 奥田重俊 - 秋山 㑆(1985)： 雑草研究 $30(3), 200 \sim 207$.
53）酒井 博 - 佐藤徳雄 - 奥田重俊 - 秋山 㑆 (1987)： 雑草研究 $32(3), 223 \sim 231$.

54）沢村 浩(1988)：植調 22(4)，19〜30.

55）篠原秀巳(1986)：自給飼料 6，3８．

56）清水矩宏 (1978)：第 6 回雑草防除夏季研究会テキス 卜 $23 \sim 68$.

57）杉本安寛・上野昌彦・仁木螈雄（1985）：日草誌 30 (4), 396 403.

58）杉本安寛・上野昌彦・仁木䉷雄（1985）：日草誌 30 (4), 404 410.

59）高野信雄・佳山良正・川鍋祐夫 : 粗飼料・草地ハン ドブック，養賢堂，東京 (1989).

(1990年 4 月 2 日受理) 